\title{
Sequence Characterized Amplified Regions Linked to Rust Resistance Genes in the Common Bean
}

\author{
Ronan Xavier Corrêa, M. R. Costa, P. I. Good-God, V. A. Ragagnin, F. G. Faleiro, \\ M. A. Moreira, and E. G. de Barros*
}

\begin{abstract}
Uromyces appendiculatus (Pers.) Unger, the causative fungus of rust in common beans (Phaseolus vulgaris $\mathbf{L}$.), consists of many pathotypes or pathogenic races. Cultivar Ouro Negro is resistant to most pathotypes detected in Brazil in the last few decades. We attempted to identify molecular markers linked to a rust resistance gene block present in Ouro Negro. DNA samples extracted from homozygous near isogenic $\mathrm{BC}_{3} \mathrm{~F}_{2: 3}$ lines derived from a cross between susceptible cultivar US Pinto 111 and Ouro Negro were grouped, following greenhouse inoculations, into two contrasting bulks, one containing only resistant and the other only susceptible plants. The bulks were amplified with 605 random primers and two of them amplified bands which were heteromorphic between the two bulks. These random amplified polymorphic DNA (RAPD) bands were transformed into sequence characterized amplified regions (SCARs) SCARBA08 and SCARF10. The rust resistance-susceptibility phenotypes and the molecular genotypes with the two SCAR markers of $303 \mathrm{~F}_{2: 3}$ families from US Pinto $111 \times$ Ouro Negro were determined. SCARBA08 and SCARF10 were determined to be $4.3 \pm 1.2$ and $6.0 \pm 1.3$ centimorgans $(\mathrm{cM})$ from the rust resistance locus, respectively. These markers are being used in combination with other markers for resistance to rust, anthracnose, and angular leaf spot previously identified in our laboratory to aid the indirect selection of desirable plants in segregating populations in which Ouro Negro has been used as donor parent.
\end{abstract}

$\mathrm{M}$ OST COMMON BEAN cultivars are susceptible to rust, caused by the fungus Uromyces appendiculatus. Field trials have shown losses of up to $68 \%$ in the state of Minas Gerais, Brazil (Vieira, 1983) and of about 75\% in Puerto Rico (Velez-Martinez et al. 1989) because of $U$. appendiculatus infection. Several reports indicate that resistance to this disease is controlled by major single dominant genes (Vieira, 1983; Stavely, 1984; Faleiro, 1997). However, there are also reports of resistance determined by a single recessive gene (Zaiter et al., 1989), by two genes (Finke et al., 1986), by two complementary dominant genes (Grafton et al., 1985), and by two independent genes (Grafton et al., 1985). The rust resistance genes identified in common beans have been compiled and a uniform nomenclature has been proposed (Kelly et al., 1996). At least 11 genes have been identified so far $(U r-1$ to $U r-11)$ (Kelly et al., 1996; Stavely, 1998). Most of them confer resistance

Ronan Xavier Corrêa, M.R. Costa, P.I. Good-God, V.A. Ragagnin, F.G. Faleiro, Instituto de Biotecnologia Aplicada à Agropecuária (BIOAGRO), Universidade Federal de Viçosa (UFV), 36571-000 Viçosa, MG, Brazil. M.A. Moreira, Departamento de Bioquímica e Biologia Molecular/BIOAGRO, E.G. de Barros, Departamento de Biologia Geral/BIOAGRO, UFV, 36571-000, Viçosa, MG, Brazil. Received 3 March 1999.*Corresponding author (ebarros@mail. ufv.br).

Published in Crop Sci. 40:804-807 (2000). to multiple races of $U$. appendiculatus, indicating that they are organized in clusters of race-specific genes.

DNA amplification of near isogenic lines (NILs) (Paran et al., 1991; Martin et al., 1991) or of contrasting DNA bulks from segregating populations (Michelmore et al., 1991) can be used to detect RAPD (Williams et al., 1990; Welsh and McClelland, 1990) markers in close proximity to disease resistance genes. During the development of NILs, these two strategies can be combined by constructing DNA bulks from $\mathrm{BC}_{\mathrm{n}} \mathrm{F}_{2: 3}$ individuals from each of two contrasting NILs. This method increases the chance that markers will be identified close to the gene of interest (Michelmore et al., 1991; Haley et al., 1993; Miklas et al., 1993).

Several RAPD markers associated with genes conferring resistance to rust in common bean have been identified (Miklas et al, 1993; Haley et al., 1993.; Johnson et al., 1995). In some cases, the application of these markers has been restricted to the laboratories where they were identified because of reproducibility problems with this technique (Kesseli et al., 1992; Weden et al., 1992). Sequence characterized amplified regions (Kesseli et al., 1992) and allele-specific associated primers (ASAP) (Weeden et al., 1992) have been proposed as alternative procedures to increase the reproducibility of the RAPD technique. SCARs identify a specific locus by amplification with a defined oligonucleotide primer pair (Paran and Michelmore, 1993). In addition, in many cases these markers can be detected without the need of the gel electrophoresis step by staining the amplification products with ethidium bromide in the amplification reaction tube (Dedryver et al., 1996; Melotto et al., 1996). In the common bean, several SCARs associated with genes for disease resistance have been identified (Adam-Blondon et al., 1994; Melotto et al., 1996).

This work describes the identification of two RAPD markers associated with rust resistance in common beans and their use to develop highly reproducible SCAR markers.

\section{MATERIAL AND METHODS}

\section{Genetic Material and Biological Assays}

Two groups of homozygous $\mathrm{BC}_{3} \mathrm{~F}_{2}$ common bean NILs derived from a cross between resistant cultivar Ouro Negro (donor parent) and susceptible cultivar US Pinto 111 (recurrent parent) and contrasting for rust resistance/susceptibility were used. After the first two backcrosses the resistant plants were fingerprinted by the RAPD technique to select those

Abbreviations: ASAP, allele-specific associated primers; bp, base pairs; cM, centimorgan; NIL, near isogenic line; RAPD, random amplified polymorphic DNA; SCAR, sequence characterized amplified region. 
closer to the recurrent parent. Ouro Negro is a black seeded Mesoamerican cultivar derived from accession Honduras 35. It is resistant to all 13 pathotypes of $U$. appendiculatus identified in the state of Minas Gerais, Brazil (Faleiro, 1997) and has maintained resistance to all pathotypes for several decades since its introduction into Brazil (Vieira, 1983).

Segregation analyses were performed by the chi-square test and the genetic distances were calculated by the Kosambi function with the aid of the program Mapmaker 3.0, with a LOD score of 3.0 and a maximum recombination fraction of 35\% (Lander et al., 1987; Lincoln et al., 1992). For the linkage analyses between the resistance gene block and the molecular markers, a segregating population of $303 \mathrm{~F}_{2}$ individuals derived from a cross between US Pinto 111 and Ouro Negro was used. The resistant-susceptible phenotypes of the $\mathrm{F}_{2}$ and $\mathrm{BC}_{3} \mathrm{~F}_{2}$ plants were confirmed by inoculation of 12 individuals derived from each $\mathrm{F}_{2}$ or $\mathrm{BC}_{3} \mathrm{~F}_{2}$ plant with $U$. appendiculatus Pathotypes 2, 8, 10, and 11 (Faleiro, 1997) using the multiple inoculation technique (Stavely, 1983). All inoculations were conducted 12 $\mathrm{d}$ after sowing with a suspension containing $2 \times 10^{4}$ spores per $\mathrm{mL}$ of water and $0.03 \%(\mathrm{v} / \mathrm{v})$ polysorbate 20 . The spores were applied to the first trifoliate leaves with approximately $2 / 3$ of its full development, with the aid of a paint brush.

After inoculation, the plants were kept in a mist chamber $\left(20 \pm 1^{\circ} \mathrm{C}\right.$ and $>95 \%$ relative humidity) for $48 \mathrm{~h}$ under a 12-h photoperiod, and were then transferred to the greenhouse. Twenty days after inoculation disease symptoms were evaluated using the scale proposed by Stavely et al. (1983).

The pathotypes used were collected in the state of Minas Gerais, Brazil, and classified by inoculation of eight differential cultivars (Kentucky Wonder 814, Early Gallatin, 51051, NEP-2, Ecuador 299, Olathe, Mexico 309, and Redlands Pioneer) which have been proposed by Mora-Nuñes et al. (1992) to identify $U$. appendiculatus pathotypes that occur in Brazil. Spores of these pathotypes are kept in the Fungal Collection of the Biotechnology Center of the Federal University of Viçosa, MG, Brazil, and can be requested from Dr. Everaldo G. de Barros (ebarros@mail.ufv.br).

\section{Identification, Cloning, and Characterization of RAPD Markers}

Equimolar amounts of DNA extracted from four $\mathrm{BC}_{3} \mathrm{~F}_{2}$ homozygous resistant and four susceptible plants were used to construct two contrasting DNA bulks. DNA extraction was according to a standard CTAB method (Doyle and Doyle, 1990). The DNA bulks were amplified by the RAPD technique (Williams et al., 1990; Welsh and McClelland, 1990), with 605 random decamer primers (Operon Technologies, Alameda, CA). The reaction volumes, reagent concentrations, and amplification conditions used were described by Corrêa et al.
(1999). The amplification products were analyzed on $1.2 \%$ $(\mathrm{w} / \mathrm{v})$ agarose gel $(100 \mathrm{~V}$ for $4 \mathrm{~h})$, stained with ethidium bromide $(0.2 \mathrm{mg} / \mathrm{mL})$, and visualized under UV light.

Heteromorphic DNA fragments distinguishing the two bulks were tested in the $303 \mathrm{~F}_{2}$ individuals to determine their distance to the resistance gene block. Those that were close to the gene block (less than $10 \mathrm{cM}$ ) were cloned in the vector pGEM-T Easy (Promega, Madison, WI). Competent JM109 Escherichia coli cells were transformed (Ausubel, 1998) and mini-prep DNA from white colonies was sequenced with M13 universal primers flanking the insert (Sanger et al., 1977). On the basis of the sequencing data, two specific SCAR primers were designed and synthesized for each RAPD marker. Synthesis of primers was performed by GIBCO-BRL/Life Technologies (Rockville, MD).

\section{SCAR Analysis}

DNA samples extracted from the $303 \mathrm{~F}_{2}$ individuals in the segregating population were amplified in $25-\mu \mathrm{L}$ reactions. The same reagents and concentrations were used as in the RAPD reactions, except the primer was replaced by 5 picomoles of pertinent SCAR primer. The thermocycler was programmed for an initial denaturation step of $94^{\circ} \mathrm{C}$ for $3 \mathrm{~min}$ followed by 35 cycles $\left(94^{\circ} \mathrm{C} / 15 \mathrm{~s}, 65^{\circ} \mathrm{C} / 1 \mathrm{~min}, 72^{\circ} \mathrm{C} / 1 \mathrm{~min} 30 \mathrm{~s}\right)$ and one final extension step at $72^{\circ} \mathrm{C}$ for $7 \mathrm{~min}$. DNA from 303 individuals of the segregating population and the corresponding progenitors were amplified. The amplification products were analyzed as described for the RAPD technique.

\section{RESULTS AND DISCUSSION Phenotypic Analyses and Identification of RAPD Markers}

The numbers of resistant and susceptible $F_{2}$ plants determined with the four $U$. appendiculatus pathotypes fit a 3:1 ratio (Table 1). The genotypic ratio based on the symptoms of the corresponding $\mathrm{F}_{3}$ families fit a 1:2:1 ratio (Table 1), confirming that a single dominant gene, or gene block, confers resistance to rust in cultivar Ouro Negro (Faleiro, 1997).

Among 605 decamer primers only two revealed polymorphisms between the two DNA bulks made from contrasting NILs (Fig. 1). Two bands of 530 and 1072 base pairs (bp) were amplified with primers OPBA08 and OPF10, respectively. These markers $\left(\mathrm{OPBA} 08_{530 \mathrm{C}}\right.$ and OPF $10_{1,072 \mathrm{C}}$ ) were linked in coupling phase to the resistance gene block when tested in $303 \mathrm{~F}_{2}$ plants derived from a cross between US Pinto 111 and Ouro

Table 1. Inheritance and genetic linkage of molecular markers and the rust resistance gene block $(R)$ in an $F_{2: 3}$ population derived from a cross between cultivars US Pinto 111 and Ouro Negro.

\begin{tabular}{|c|c|c|c|c|c|c|}
\hline Locus & $\begin{array}{c}\text { Generation } \\
\text { analyzed }\end{array}$ & $\begin{array}{c}\text { Expected } \\
\text { ratio in } F_{2}\end{array}$ & $\begin{array}{l}\text { Observed } \\
\text { ratio }\end{array}$ & Chi-Square & Probability & $\begin{array}{c}\text { Genetic } \\
\text { distance } \dagger\end{array}$ \\
\hline \multirow[t]{2}{*}{$\mathbf{R}$} & $\mathbf{F}_{2}$ & $3: 1+$ & 224:79 & 0.19 & 0.67 & - \\
\hline & $\mathbf{F}_{2: 3}$ & $1: 2: 1 \S$ & 66:155:82 & 1.75 & 0.42 & - \\
\hline OPF10 $_{1,072 \mathrm{C}}$ & $\mathbf{F}_{2}$ & $3: 1$ & 221:82 & 0.69 & 0.41 & - \\
\hline OPBA8 $_{530 \mathrm{C}}$ & $\mathbf{F}_{2}$ & $3: 1$ & 221:88 & 1.98 & 0.16 & - \\
\hline \multirow{2}{*}{ R/OPF10 $1,072 \mathrm{C}$} & $\mathbf{F}_{2}$ & 9:3:3:1 I & 217:7:6:73 & 256.18 & $<\mathbf{0 . 0 0 0 1}$ & $7.0 \pm 1.41$ \\
\hline & $\mathbf{F}_{2: 3}$ & 9:3:3:1 & 214:7:6:76 & 272.19 & $<\mathbf{0 . 0 0 0 1}$ & $4.3 \pm 1.19$ \\
\hline \multirow[t]{2}{*}{ R/OPBA $8_{530 C}$} & $\mathbf{F}_{2}$ & 9:3:3:1 & 213:11:6:73 & 247.35 & $<\mathbf{0 . 0 0 0 1}$ & $8.6 \pm 1.53$ \\
\hline & $\mathbf{F}_{2: 3}$ & 9:3:3:1 & 210:11:6:76 & 263.51 & $<\mathbf{0 . 0 0 0 1}$ & $6.0 \pm 1.33$ \\
\hline
\end{tabular}

$\dagger$ Genetic distances in centiMorgans (Kosambi) followed by standard deviation.

+ Expected ratio for dominant monogenic inheritance in the $F_{2}$ progeny (3 resistant, $R \_1$ susceptible, rr).

$\$$ Expected ratio for dominant monogenic inheritance in the $F_{2}$ progeny based on $F_{2: 3}$ families (1 resistant, RR: 2 resistant, Rr: 1 susceptible, rr).

II Expected ratio for segregation of two independent genes in the $F_{2}$ progeny $\left(R \_I+: R \_-: r r /+: r r /-\right)$ and data confirmed in the $F_{2: 3}$ families. 


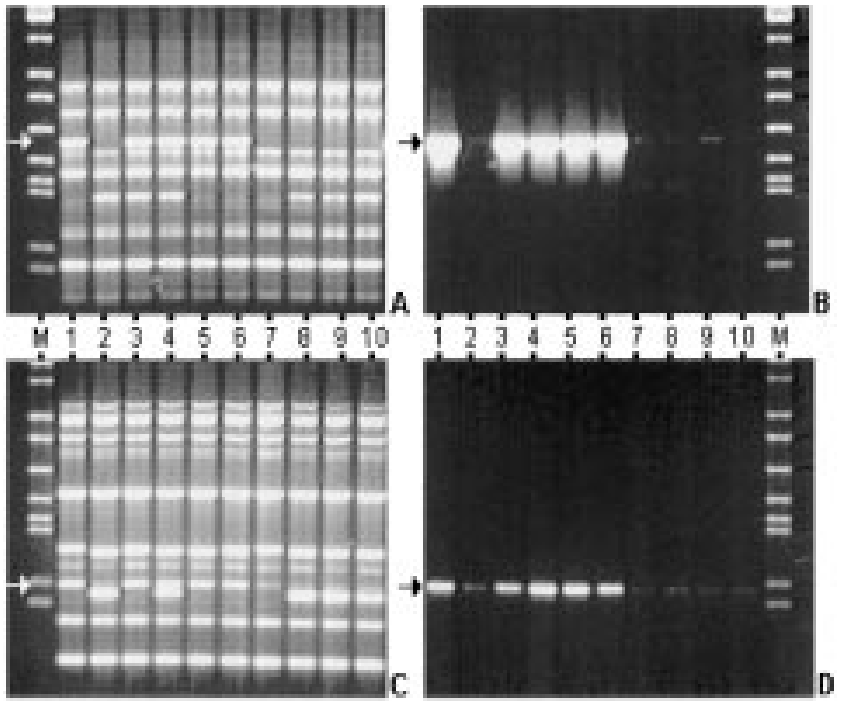

Fig. 1. Electrophoretic analyses of DNA amplification products showing (A) RAPD markers OPF10 ${ }_{1,072}$, (B) SCAR marker SCARF10, (C) RAPD marker OPBA08 ${ }_{530 \mathrm{C}}$, and (D) SCAR marker SCARBA08. Lanes are as follows: 1, cv. Ouro Negro; 2, cv. US Pinto 111; 3 through 6, $F_{2}$ resistant plants; and 7 through 10, F2 susceptible plants. $M$ refers to lambda phage DNA digested with EcoRI, HindIII, and BamHI restriction enzymes (size markers).

Negro and were 8.6 and $7.0 \mathrm{cM}$, respectively, distant from the resistance gene block (Table 1). However, when the resistant-susceptible phenotypes of these plants were evaluated by inoculation of the corresponding $\mathrm{F}_{2: 3}$ families $(12 \times 303$ individuals $)$, these markers mapped closer to the resistance gene block, at 6.0 and $4.3 \mathrm{cM}$, respectively. This was because the initial classification of three $F_{2}$ plants gave erroneous scores which were detected by analyzing $\mathrm{F}_{2: 3}$ families (Table 1 ).

Haley et al. (1993) identified a RAPD marker of 970 bp with primer OPF10 close to a rust resistance gene block $(2.1 \pm 1.5 \mathrm{cM})$ present in Mesoamerican common bean cultivars. This gene block was identified as $U r-5$ by Kelly et al. (1996). The relatively small size difference between the marker we identified (1072 bp) and that identified by Haley et al. (1993) might suggest that they tag the same locus. However, allelism tests are needed to clarify this situation. Apparently, the gene block present in Ouro Negro does not correspond to Ur-5. Tests done in our laboratory indicate that rust resistant cultivar Mexico 309, which harbors $U r-5$ differs from cultivar Ouro Negro in relation to resistance-susceptibility to some $U$. appendiculatus pathotypes isolated in Brazil (data not shown). Tests done with Ouro Negro by Dr. James R. Stavely (USDA-ARS, Beltsville, MD) also indicate that it does not possess $U r-3, U r-4, U r-5$, or $U r-6$. The tests he conducted suggest that the resistance gene block present in cultivar Ouro Negro might be an allele or linked to $U r-11$, which is present in PI 181996 and PI 190078 (1999, personal communication).

\section{Development and Analyses of SCAR Markers}

Two pairs of primers were designed and synthesized on the basis of the sequences of the cloned RAPD fragments (Michelmore et al., 1991). The sequences of the SCAR primers flanking marker OPF $10_{1,072 \mathrm{C}}$ are $5^{\prime}$ GGA AGC TTG GTG AGC AAG GA 3' and 5' GGA AGC TTG GCT ATG ATG GT $3^{\prime}$ and the corresponding marker amplified was designated SCARF10. The sequences of SCAR primers flanking marker OPBA $8_{530 \mathrm{C}}$ are 5' CCA CAG CCG ACG GAG GAG 3' and 5' GCC ATG TTT TTT GTC CCC $3^{\prime}$ and the corresponding marker amplified was designated SCARBA8. Figure 1 depicts the amplification patterns showing RAPD and SCAR markers in the progenitors, and $\mathrm{F}_{2}$ resistant and susceptible plants.

In this work, only two of 605 different 10-mer primers used to amplify the contrasting rust resistant vs. susceptible bulks revealed polymorphisms. In other crosses contrasting for rust resistance involving cultivar Ouro Negro, 800 primers were tested revealing only one polymorphism between the bulks (Ragagnin et al., 1998). The SCAR markers we developed are being now used in our breeding program to characterize and select individuals carrying the Ouro Negro rust resistance gene block. They are highly reproducible and can be used in association with marker OPX11 which is also linked to the resistance gene block present in Ouro Negro (Ragagnin et al., 1998). Those authors obtained a $100 \%$ selection efficiency using the SCAR markers associated with the RAPD marker they identified. Our attempts to transform marker OPX11 into a SCAR marker were unsuccessful. DNA from both resistant and susceptible plants was amplified with the designed SCAR primers within a wide range of annealing temperatures (data not shown).

\section{ACKNOWLEDGMENTS}

This work is part of the $\mathrm{PhD}$ Thesis of the first author and was financed by grants from the Brazilian Government: PADCT/FINEP \#64.93.0430.00 and FAPEMIG \#CBS 1074/ 96. RXC was supported by a fellowship from CNPq. The authors wish to thank Dr. M. Melotto for her helpful suggestions during the preparation of this manuscript and also Dr. James R. Stavely for providing unpublished data concerning the identity of the resistance gene block present in Ouro Negro.

\section{REFERENCES}

Adam-Blondon, A.F., M. Sevignac, H. Bannerot, and M. Dron. 1994 SCAR, RAPD and RFLP markers linked to a dominant gene (Are) conferring resistance to anthracnose in common bean. Theor. Appl. Genet. 88:865-870.

Ausubel, F. 1998. Current protocols in molecular biology. John Wiley \& Sons, Teton Data Systems, New York.

Corrêa, R.X., R.V. Abdelnoor, F.G. Faleiro, C.D. Cruz, M.A. Moreira, and E.G. Barros. 1999. Genetic distances in soybean based on RAPD markers. Bragantia 58(1):15-22.

Dedryver, F., M.F. Jubier, J. Thouvenin, and H. Goyeau. 1996. Molecular markers linked to the leaf rust resistance gene Lr24 in different wheat cultivars. Genome 39:830-835.

Doyle, J.J. and J.L. Doyle. 1996. Isolation of plant DNA from fresh tissue. Focus 12:13-15.

Faleiro, F.G. 1997. Identificação de raças, diversidade genética de Uromyces appendiculatus var. appendiculatus e herança da resistência no feijoeiro. M. S. Thesis. Federal University of Viçosa, Viçosa, MG, Brazil

Finke, M.L., D.P. Coyne, and J.R. Steadman. 1986. The inheritance and association of resistance to rust, common bacterial blight, plant 
habit and foliar abnormalities in Phaseolus vulgaris L. Euphytica 35:969-982.

Grafton, K.F., G.C. Weiser, L.J. Littlefield, and J.R. Stavely. 1985. Inheritance of resistance to two races of leaf rust in dry edible bean. Crop Sci. 25:537-539.

Haley, S.D., P.N. Miklas, J.R. Stavely, J. Byrum, and J.D. Kelly. 1993. Identification of RAPD markers linked to a major rust resistance gene block in common bean. Theor. Appl. Genet. 86:505-512.

Johnson, E., P.N. Miklas, J.R. Stavely, and J.C. Martine-Cruzado. 1995. Coupling- and repulsion-phase RAPDs for marker-assisted selection of PI 181996 rust resistance in common bean. Theor Appl. Genet. 90:659-664.

Kelly, J.D., J.R. Stavely, and P.N. Miklas. 1996. Proposed symbols for rust resistance genes. Annu. Rep. Bean Imp. Coop. 39:25-31.

Kesseli, R.V., I. Paran, and R. W. Michelmore. 1992. Efficient mapping of specifically targeted genomic regions and the tagging of these regions with reliable PCR-based genetic markers. p. 31-36. In Proc. Symp. Applications of RAPD Technology to Plant Breeding. Joint Plant Breeding Symposia Series. 1 Nov. Minneapolis, ASA, Madison, WI.

Lander, E., P. Green, J. Abrahamson, A. Barlon, M. Daley, S. Lincoln, and L. Newburg. 1987. MAPMAKER: an interactive computer package for constructing primary genetic linkages maps of experimental and natural populations. Genomics 1:174-181.

Lincoln, S., M. Daly, and E. Lander. 1992. Constructing genetic maps with MAPMAKER/EXP 3.0. 3.ed. s.l., Whitehead Institute, Technical Report. Whitehead Institute, Cambridge, MA.

Martin, G.B., J.G.K. Williams, and S.D. Tanksley. 1991. Rapid identification of markers linked to a Pseudomonas resistance gene in tomato by using random primers and near-isogenic lines. Proc. Natl. Acad. Sci. (USA) 88:2336-2340.

Melotto, M., L. Afanador, and J.D. Kelly. 1996. Development of a SCAR marker linked to the $I$ gene in common bean. Genome 39:1216-1219.

Michelmore, R.W., I. Paran, and R.V. Kesseli. 1991. Identification of markers linked to disease-resistance genes by bulked segregant analysis: a rapid method to detect markers in specific genomic regions by using segregating populations. Proc. Natl. Acad. Sci. (USA) 88:9828-9832.

Miklas, P.N., J.R. Stavely, and J.D. Kelly. 1993. Identification and potential use of a molecular marker for rust resistance in common bean. Theor. Appl. Genet. 85:745-749.

Mora-Nuñes, O.A., C. Vieira, L. Zambolim. 1992. Variedades diferenciadoras de feijão para identificação de raças fisiológicas de Uro myces phaseoli var. typica Arth. Ceres 39:391-404.
Paran, I., R. Kesseli, and R.W. Michelmore. 1991. Identification of restriction fragment length polymorphism and random amplified polymorphic DNA markers linked to downy mildew resistance genes in lettuce, using near-isogenic lines. Genome 34:1021-1027.

Paran, I., and R.W. Michelmore. 1993. Development of reliable PCRbased markers linked to downy mildew resistance genes in lettuce. Theor. Appl. Genet. 85:985-993.

Ragagnin, V.A., W.S. Vinhadelli, F.G. Faleiro, R.X. Corrêa, M.A Moreira, and E.G. Barros. 1998. Identificação de marcadores RAPD ligados a genes de resistência do feijoeiro à ferrugem. Genet. Mol. Biol. 21(supplement):389.

Sanger, F., S. Nicklen, and A.R. Coulson. 1977. DNA sequencing with chain terminating inhibitors. Proc. Natl. Acad. Sci. (USA) 74:5463-5467.

Stavely, J.R. 1983. A rapid technique for inoculation of Phaseolus vulgaris with multiple pathotypes of Uromyces phaseoli. Phytopathology 73:676-679.

Stavely, J.R. 1984. Genetics of resistance to Uromyces phaseoli in a Phaseolus vulgaris line resistant to must races of the pathogen. Phytopathology 74:339-344.

Stavely, J.R. 1998. Recombination of two major dominant rust resistance genes that are linked in repulsion. Annu. Rep. Bean Imp. Coop. 41:17-18.

Stavely, J.R., G.F. Freytag, J.R. Steadman, and H.F. Schwartz. 1983 The 1983 Bean Rust Workshop. Annu. Rep. Bean Imp. Coop. 26:4-6.

Velez-Martinez, H., J. Lopez-Rosa, G.F. Freytag. 1989. Determination of yield loss caused by rust [Uromyces phaseoli (Reben) Wint.] in common bean (Phaseolus vulgaris L) in Puerto Rico. Annu. Rep. Bean Improv. Coop. 32:134-135.

Vieira, C. 1983. Doenças e pragas do feijoeiro. U.F.V., Imprensa Universitária Viçosa, MG, Brazil.

Weeden, N.F., G.M. Timmerman, M. Hemmat, B.E. Kneen, and M.A Lodhi. 1992. Inheritance and reliability of RAPD markers. p. 12-17. In Proc. Symp. Applications of RAPD Technology to Plant Breeding. Joint Plant Breeding Symposia Series. 1 Nov. Minneapolis, ASA, Madison, WI.

Williams, J.G.K., A.R. Kubelik, K.J. Livak, J.A. Rafalski, and S.V. Tingey. 1990. DNA polymorphisms amplified by arbitrary primers are useful as genetic markers. Nucl. Acids Res. 18:6531-6535.

Welsh, J., and M. McClelland. 1990. Fingerprinting genomes using PCR with arbitrary primers. Nucl. Acids Res. 18:7213-7218.

Zaiter, H.Z., D.P. Coyne, J.R. Steadman. 1989. Inheritance of resistance to a rust isolate in beans. Annu. Rep. Bean Improv. Coop. 32:126-127. 